\title{
RESEARCH OF THE STATE OF INTERNAL SURFACES OF A SUPERCRITICAL WATER LOOP AFTER A SESSION OF IRRADIATION
}

\author{
A.I. Azarov, A.S. Bakai, V.N. Boriskin, V.A. Bocharov, Yu.V. Gorenko, M.A. Dolzhek, \\ E.I. Zaitsev, V.A. Momot, V.I. Solodovnikov, V.Yu. Tytov, S.V. Shelepko \\ National Science Center "Kharkov Institute of Physics and Technology", Kharkiv, Ukraine \\ E-mail: bocharov@kipt.kharkov.ua
}

Made of austenitic steel at the NSC KIPT, the supercritical water convection loop Loop-1a was running for more than 500 hours in the first experimental session (in 2011). The materials tested in the loop were placed into a stream of water (more than $50 \mathrm{~g} / \mathrm{s}$ ) at a temperature of $350 \ldots 400^{\circ} \mathrm{C}$, a pressure of $23 \ldots 25 \mathrm{MPa}$, and were irradiated by an electron beam with an energy of $10 \mathrm{MeV}$. Sediments that emerged on the inner surface of the loop were examined. The sediment mainly consisted of compounds of calcium and iron mixed with other elements. There is a possibility to increase corrosion induced by radiation due to dislocation damage, hydrogenation of metal and under the impact of active oxygen.

PACS: 82.80.-d; 07.35.+k; 29.20.Ej

\section{INTRODUCTION}

The commissioning of nuclear reactors cooled by supercritical water (SCW) will increase the efficiency of nuclear power plants [1]. SCW has remarkable properties - it dissolves many substances, has an increased heat capacity, etc, but has corrosive activity. The examination of the corrosive properties of SCW under the influence of radiation is an urgent task in the development of new nuclear reactors [1 - 5]. The described convection loop (Fig. 1) is made of a pipe with a diameter of $40 \mathrm{~mm}$ with a wall thickness of mainly $4 \mathrm{~mm}$ (under a heater $1 \ldots 6 \mathrm{~mm}$ ). Pipe made of steel-12X18H10T (AISI 321). Water convection with a mass flow up to $70 \mathrm{~g} / \mathrm{s}$ was carried out by heating the irradiation chamber with an electron beam of $10 \mathrm{MeV}$ energy, two external heaters and two coolers with pressures up to $25 \mathrm{MPa}$ and temperatures up to $400^{\circ} \mathrm{C}$.

\section{DEPOSITS INSIDE THE CONVECTION LOOP}

In the first session, the Loop-1a was running for more than $500 \mathrm{~h}[3,5]$. After the session, the irradiation chamber (IC) was dismantled from the loop. The scheme of the loop with the cut out IC is shown in Fig. 1.

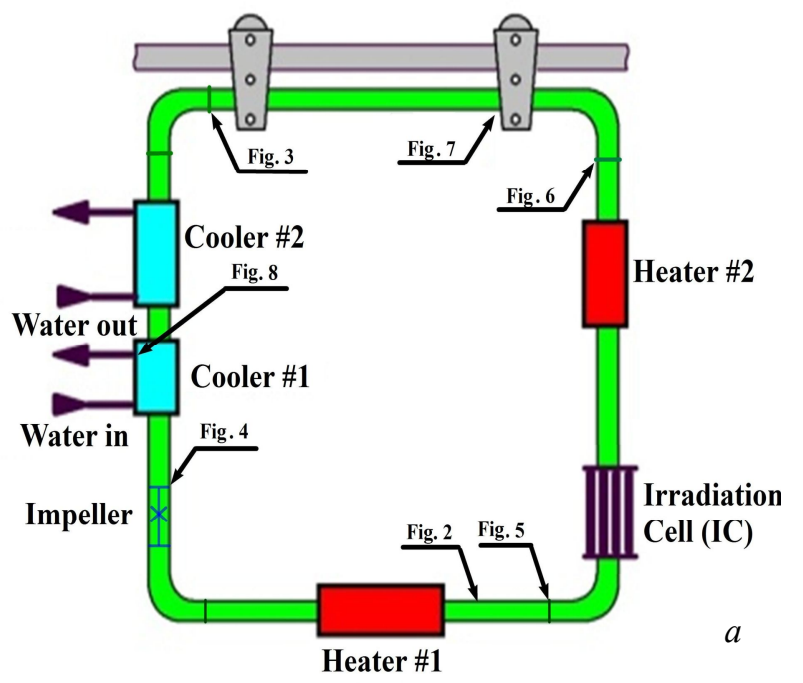

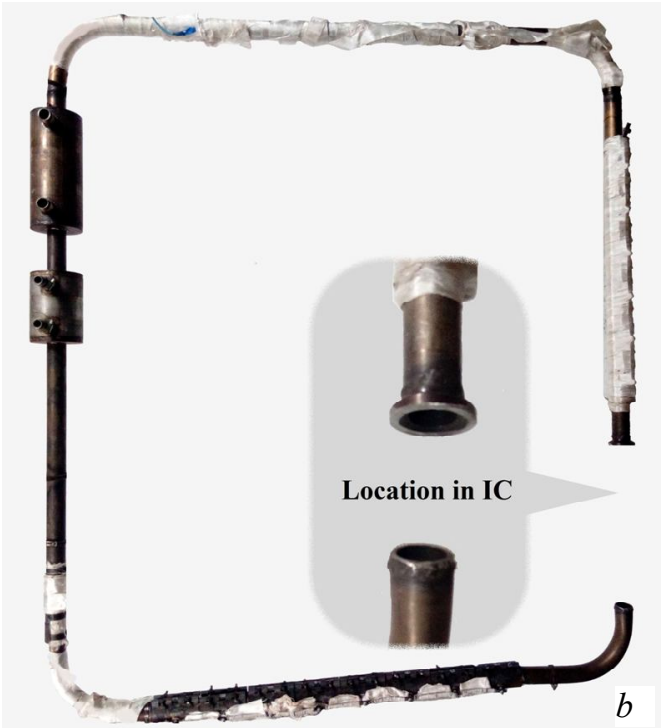

Fig. 1. Supercritical water convection loop. The scheme of the loop (a); photos inside the loop (b)

Using a miniature video camera, was shot a video of the inner surface of the loop pipe. Fig. 1 shows the location where the photos was taken inside the loop. The pipe is mainly covered by whitish sediment, which consists of grains of calcium salts (Fig. 2).

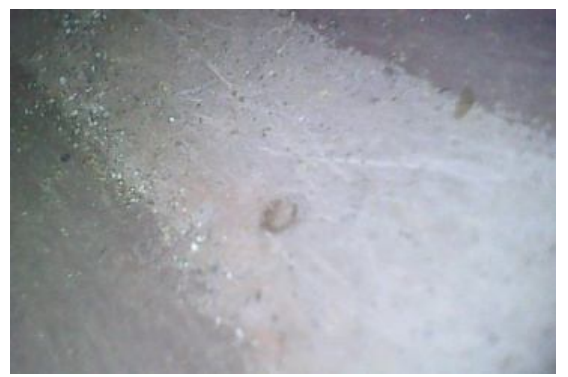

Fig. 2. Sediments on the inner surface of the pipe (lower, horizontal part), grains of calcium salts are visible

A light lilac color coating is observed on the annular welding seam (Fig. 3). Samples of sediment were taken from the inner surfaces of the loop, it was possible to collect part of the coating (sediment) at a distance of 15 and $60 \mathrm{~cm}$ from IC, to the right and left of heater № 1, as well as from the blue ring on the weld (see Fig. 3). 
Sample № 1 weighing $17 \mathrm{mg}$, sample № 2 weighing $85 \mathrm{mg}$ and sample № 3 weighing $2.7 \mathrm{mg}$ were dissolved in 5\% nitric acid, the solutions were filtered and brought to a volume of $25 \mathrm{ml}$. On the filters from samples № 1 and 2, a dark powder remained, resembling pyrolusite, weighing about $1 \mathrm{mg}$.

In August 2019, the Loop-1a with a new irradiation chamber was running for more than $500 \mathrm{~h}$, the nature of the internal sediment is basically the same as in the first session.

The composition of the sediments on the inner surface of the loop, \%

\begin{tabular}{|l|l|l|l|l|l|l|l|l|l|l|}
\hline Sample & $\mathrm{Ca}$ & $\mathrm{Cr}$ & $\mathrm{Cu}$ & $\mathrm{Fe}$ & $\mathrm{Mg}$ & $\mathrm{Mn}$ & $\mathrm{Ni}$ & $\mathrm{P}$ & $\mathrm{S}$ & $\mathrm{Sr}$ \\
\hline № 1 & 11.2 & 0.02 & 0.07 & 0.53 & 0.05 & 0.04 & 0.13 & 0.41 & 0.18 & 0.06 \\
\hline № 2 & 11.8 & 0,01 & 0.05 & 0.38 & 0.01 & 0.04 & 0.05 & 0.49 & 0.21 & 0.07 \\
\hline № 3 & 3.00 & 0.04 & 0.27 & 11.11 & 0.07 & 0.06 & 0.27 & 0.26 & 0.23 & 0.001 \\
\hline
\end{tabular}

As can be seen from the Table, a significant calcium content was found, as well as a noticeable content of heavy metals and strontium as a satellite of calcium. In the sample taken from the place of ring welding (see a blue ring, sample № 3, Fig. 3), an increased content of iron, nickel, copper and chromium was determined, which may indicate an increase of corrosion along the weld. The content of phosphorus in the sample (up to $0.5 \%$ ) confirms that corrosion of stainless steel occurs in SCW.

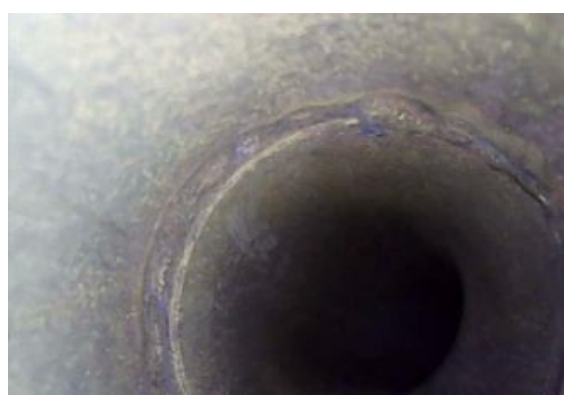

Fig. 3. The blue ring where sample № 3 is taken.

A strip of rust and a nearby bluish strip are located asymmetrically along the diameter of the annular seam

Only for $\mathrm{Cr}, \mathrm{Mg}, \mathrm{Ni}$ are the results for the first two samples very different. To assess the behavior of microimpurities in steel, its spectral analysis was performed using a Spectrolab M10 spectrometer: C - 0.06; Si $0.05 ; \mathrm{Mn}-1.07 ; \mathrm{Cr}-17.93 ; \mathrm{Ni}-9.89 ; \mathrm{P}-0.019 ; \mathrm{S}-$ $0.033 ; \mathrm{Cu}-0.17$; Mo - 0.08; V - 0.04; W - 0.05; Ti 0.62 . It was confirmed that the chemical composition corresponds to steel X18H10T according to GOST 5632-72 and SCW is being enriched with steel components.

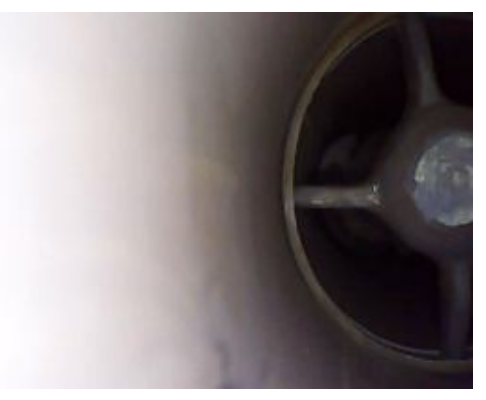

Fig. 4. Sediments on the impeller

\section{EXPERIMENTAL RESULTS}

In solutions by the emission spectral method with induction-coupled plasma, the content of elements was determined using a Shimadzu-9000 spectrometer, the main of which are shown in Table (weight \% in sediment).

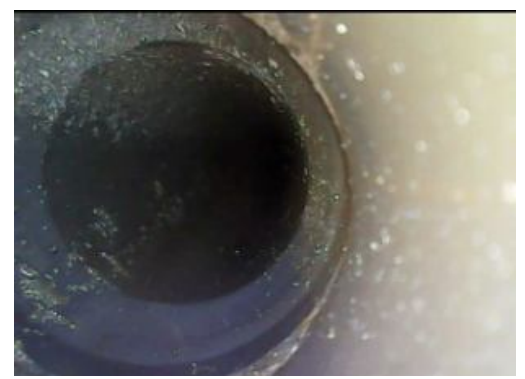

Fig. 5. The beginning of the pipe under the lower heater, the sediment layer is loose, pimples are visible

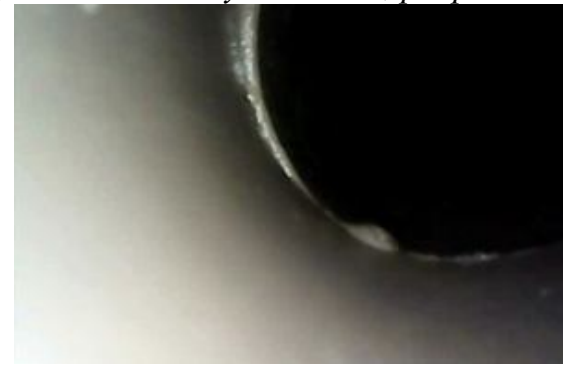

Fig. 6. The seam above the $I C$, dense sediments are mostly whitish

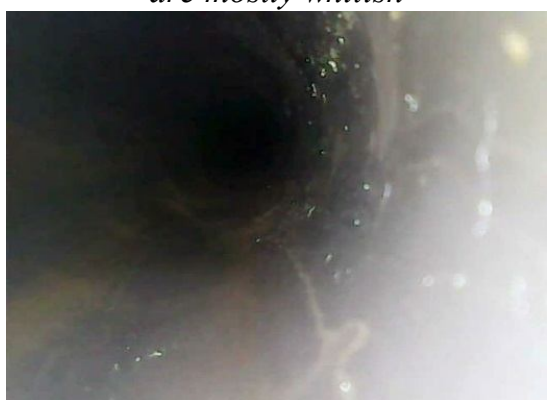

Fig. 7. Upper horizontal pipe

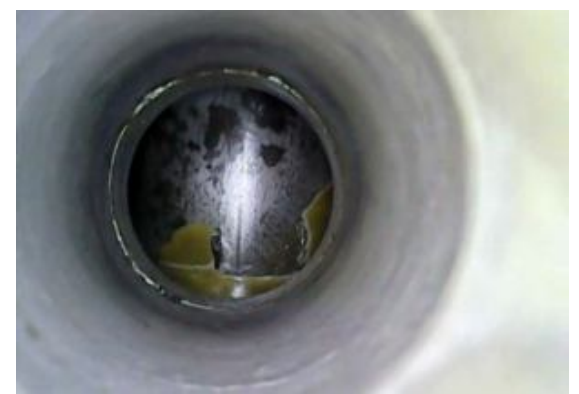

Fig. 8. The output of water from the cooler 1 
Experiment 2019 showed that sediment on the impeller swirling the SCR flow is more dense (Fig. 4) than on the straight pipe section (Fig. 7); in the heater region, the sediment layer is inhomogeneous (Fig. 5), above the irradiation chamber dense sediment (Fig. 6), yellowish lamellar sediment from recycled water in the cooler is the same as in the first session, and characterized by a high content of strontium (Fig. 8).

\section{CONCLUSIONS}

The presence of calcium, magnesium and strontium in sediments is associated with the presence of these elements in the source water. Phosphorus and sulfur came to the water undoubtedly due to corrosion.

Most sediment inside the loop is non-corrosive, and rust spots and colored sediment indicate corrosion of stainless steel. At the welds, an increased amount of sediment is observed. Blue sediment is characterized by high content of iron, chromium, copper, nickel. In the area of the heater, the sediment layer is uneven.

Sediment on the impeller is of the same type as on the straight section of the pipe, but it is more dense in appearance.

Below the irradiation chamber, sediment is loose (see Fig. 5), and above the chamber sediment is more smooth and denser (see Fig. 6). It is possible that phase transitions of the water in IC from before critical state to supercritical state and vice versa, contributes to compaction of sediment on the pipe. To clarify this statement, additional research is required.

The deposits in vertical sections of the loop are denser than in horizontal sections where stagnant zones are likely to form.

Sediment in the cooler from recycled water (see Fig. 8) is characterized by a high strontium content, even slightly higher than the calcium content. That can be explained by the lower solubility of strontium salts.
It can be argued that although in SCW is observed corrosion of stainless steel, however, the thickness of the walls of the loop practically did not change; therefore, the body of the Loop-1a loop can be used in new experiments.

\section{REFERENCES}

1. D. Guzonas, R. Novotny, S. Penttila, A. Toivonen, W. Zheng. Materials and Water Chemistry for Supercritical Water-Cooled Reactors // Woodhead Publ Ser. in Energy, Elsvier UK Ltd, Cambridge, 2018, 264 p.

2. A.S. Bakai, V.N. Boriskin, A.N. Dovbnya, S.V. Dyuldya, D. Guzonas. Supercritical Water Convection Loop for SCWR Materials Corrosion Tests under Electron Irradiation: First Results and Lessons Learned // Proc. of the $6^{\text {th }}$ Int. Symposium on Supercritical Water-Cooled Reactors (ISSCWR6), March 3-7, 2013, Shenzhen, Guangdong, China. Paper \#ISSCWR6-13062, 14 p.

3. O.S. Bakai, V.M. Boriskin, A.N. Dovbnya, S.V. Dyuldya, D.A. Guzonas. Combined Effect of Irradiation, Temperature, and Water Coolant Flow on Corrosion of Zr-, Ni-Cr, and Fe-Cr-based Alloys // J. Nucl. Eng. Rad. Sci. 2016, v. 2, Issue 1, 021007 (11 p.).

4. O.S. Bakai, V.M. Boriskin, M.I. Bratchenko, et al. Many-Channel Cell to Irradiate the Material Specimens by Electrons in the Interior of the Supercritical Water Convection Loop // Problems of Atomic Science and Technology. Series "Nuclear Physics Investigations”. 2015, № 6, p. 130-136.

5. O.S. Bakai, V.M. Boriskin, M.I. Bratchenko, et al. Regimes of Irradiation by Electrons of Samples of Materials in Supercritical Water Convection Loop // Problems of Atomic Science and Technology. Series “Nuclear Physics Investigations”. 2017, № 6, p. 185190.

Article received 30.01.2020

\section{ИССЛЕДОВАНИЕ СОСТОЯНИЯ ВНУТРЕННИХ ПОВЕРХНОСТЕЙ СВЕРХКРИТИЧЕСКОЙ ВОДЯНОЙ ПЕТЛИ ПОСЛЕ СЕАНСА ОБЛУЧЕНИЯ}

\section{А.И. Азаров, А.С. Бакай, В.Н. Борискин, В.А. Бочаров, Ю.В. Горенко, М.А. Долюек, Е.И. Зайцев, В.А. Момот, В.И. Солодовников, В.Ю. Титов, С.В. Шелепко}

Изготовленная из аустенитной стали в ННЦ ХФТИ сверхкритическая водяная конвекционная петля Loop-1а в первом экспериментальном сеансе (2011 год) проработала более 500 ч. Испытываемые в петле материалы находились в потоке воды (более 50 г/с) при температуре $350 \ldots 400^{\circ} \mathrm{C}$, давлении $23 \ldots 25$ МПа и облучались электронным пучком энергией 10 МэВ. Исследовали отложения на внутренней поверхности петли, которые состоят в основном из соединений кальция и железа с примесью других элементов. Возможно усиление коррозии под действием излучения за счет дислокационных повреждений, наводороживания и активного кислорода.

\section{ДОСЛІДЖЕННЯ СТАНУ ВНУТРІШНІХ ПОВЕРХОНЬ НАДКРИТИЧНОЇ ВОДЯНОЇ ПЕТЛІ ПІСЛЯ СЕАНСУ ОПРОМІНЕННЯ \\ О.І. Азаров, О.С. Бакай, В.Н. Боріскін, В.О. Бочаров, Ю.В. Горенко, М.О. Должсек, С.І. Зайцев, В.О. Момот, В.І. Солодовніков, В.Н. Тітов, С.В. Шелепко}

Виготовлена з аустенітної стали в ННЦ ХФТІ надкритична водяна конвекційна петля Loop-1a в першому експериментальному сеансі (2011 рік) пропрацювала понад 500 год. Випробовувані у петлі матеріали перебували в потоці води (понад 50 г/с) при температурі $350 \ldots 400^{\circ} \mathrm{C}$, тиску $23 \ldots 25$ МПа і опромінювалися електронним пучком енергією 10 МеВ. Досліджували відкладення на внутрішній поверхні петлі, які складаються в основному із сполук кальцію і заліза з домішкою інших елементів. Можливе посилення корозії під дією випромінювання за рахунок дислокаційних ушкоджень, насичення воднем і активного кисню. 